Supplement of Hydrol. Earth Syst. Sci., 23, 3503-3524, 2019

https://doi.org/10.5194/hess-23-3503-2019-supplement

(C) Author(s) 2019. This work is distributed under

the Creative Commons Attribution 4.0 License.

(c) (1)

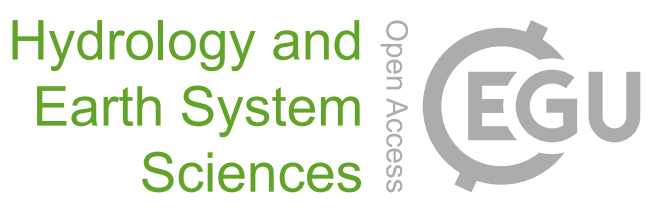

Supplement of

\title{
Trajectories of nitrate input and output in three nested catchments along a land use gradient
}

\section{Sophie Ehrhardt et al.}

Correspondence to: Sophie Ehrhardt (sophie.ehrhardt@ufz.de)

The copyright of individual parts of the supplement might differ from the CC BY 4.0 License. 


\section{Supplement}

\section{S1 Addition to material and methods}

\section{S1.1 Catchment characteristics}

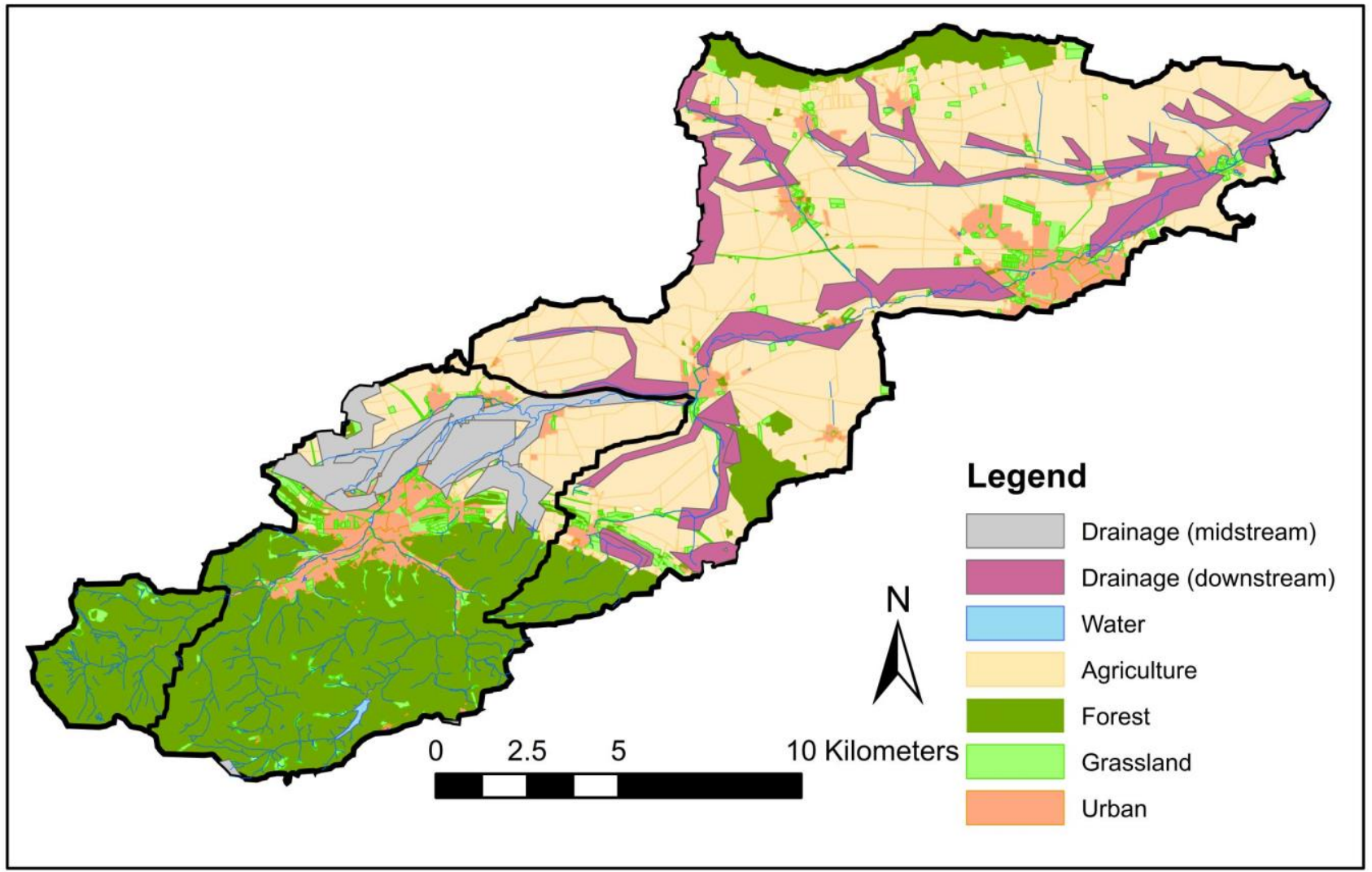

5 Figure S1.1: Map of the catchment highlighting the agricultural area that is artificially drained 
S1.2 Water quality time series of $\mathrm{NH}_{4}-\mathrm{N}$ and $\mathrm{NO}_{2}-\mathrm{N}$
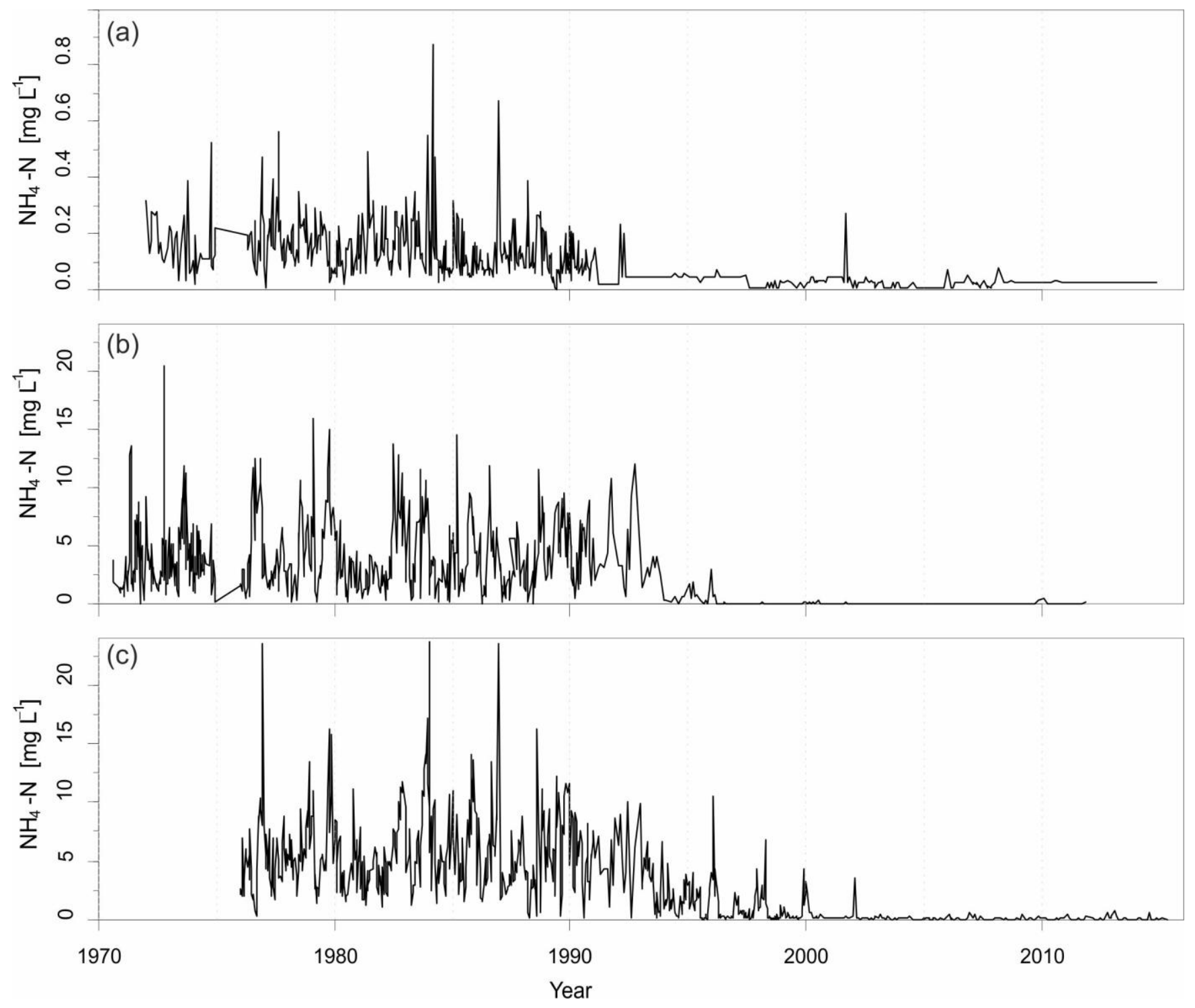

Figure S1.2.1: Time series of $\mathrm{NH}_{4}-\mathrm{N}$ concentrations. (a) Upstream; (b) Midstream; (c) Downstream. 

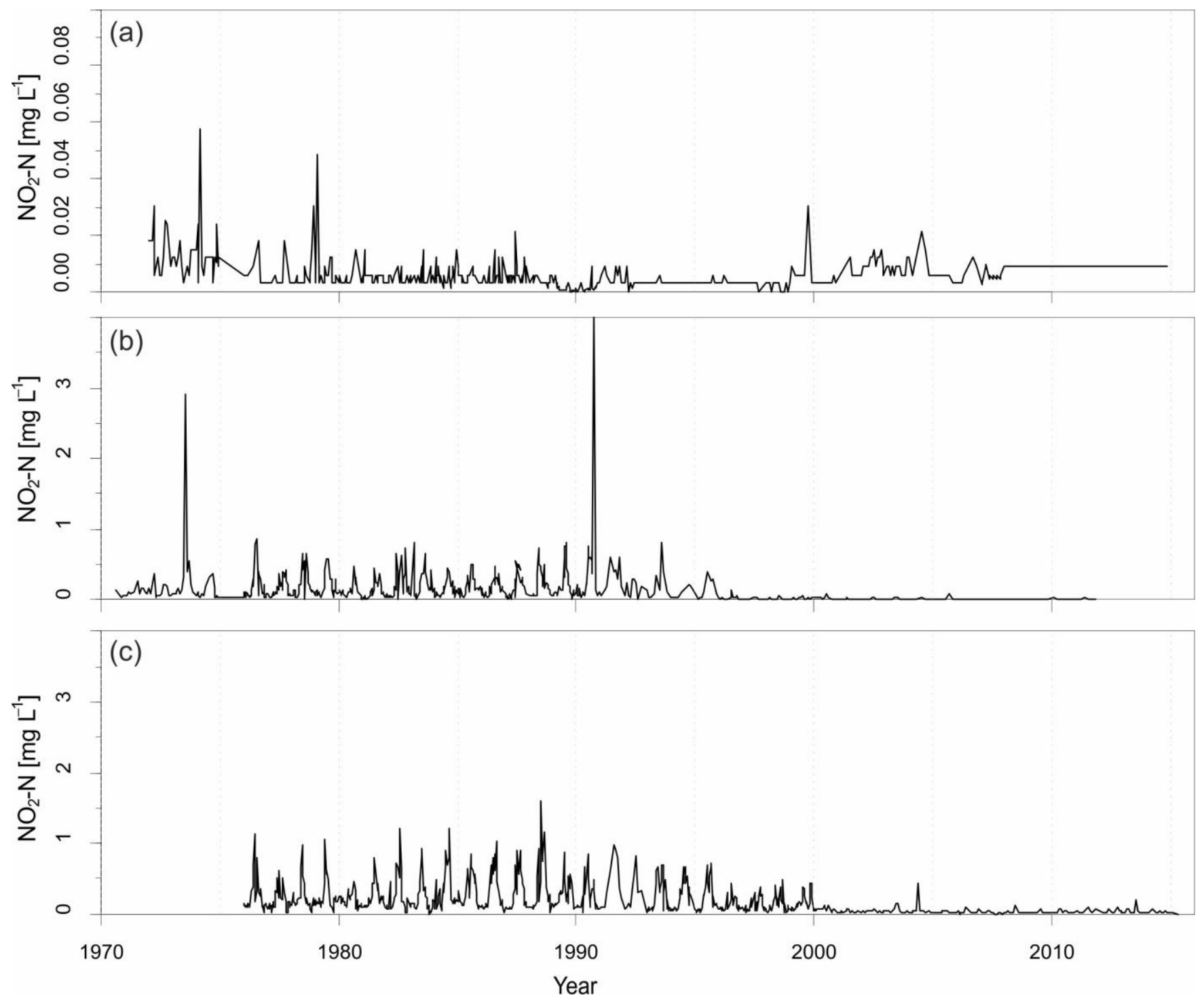

Figure S1.2.2: Time series of $\mathrm{NO}_{2}-\mathrm{N}$ concentrations. (a) Upstream; (b) Midstream; (c) Downstream. 


\section{S.1.2.3 Estimation of $\mathrm{NO}_{3}-\mathrm{N}$ contribution from wastewater borne $\mathrm{NH}_{4}-\mathrm{N}$}

The assumption that agricultural, diffuse input was the main source of $\mathrm{NO}_{3}-\mathrm{N}$, needed an investigation of the possible amount of $\mathrm{NO}_{3}-\mathrm{N}$ stemming from nitrified $\mathrm{NH}_{4}-\mathrm{N}$ released by the WWTPs.

We estimated the maximal amount of waste water born $\mathrm{NO}_{3}-\mathrm{N}$ from the highest nitrification rates taken from other studies

5 (Webster et al., 2003; Mulholland et al., 2000, Tank et al., 2000). The highest rate was $0.19 \mathrm{~g} \mathrm{~m}^{-2} \mathrm{~d}^{-1}$ (Tank et al., 2000). Note that we assume that this rate is constant over the year and that $\mathrm{NH}_{4}-\mathrm{N}$ was always unlimitedly available.

To calculate the river area, we used the stream length und mean stream width between the two WWTPs and corresponding stations Mid- and Downstream (Table S.1.2.3). This estimation took the relocation of the WWTP Wernigerode in 1995 into account. The estimation of waste water born $\mathrm{NO}_{3}-\mathrm{N}$ revealed a maximal contribution of $5.2 \%$ stemming from nitrification

10 over the years. Hence, in-stream nitrification of $\mathrm{NH}_{4}-\mathrm{N}$ release from point sources did not contributed significantly to riverine $\mathrm{NO}_{3}$ loads or concentrations.

Table S.1.2.3: Estimation of $\mathrm{NO}_{3}-\mathrm{N}$ contribution by in-stream nitrification of waste water born $\mathrm{NH}_{4}-\mathrm{N}$ in the anthropogenically impacted subcatchments

\begin{tabular}{|c|c|c|c|}
\hline & $\begin{array}{l}\text { Midstream } \\
\text { before } 1995\end{array}$ & $\begin{array}{l}\text { Midstream } \\
\text { after } 1995\end{array}$ & Downstream \\
\hline $\mathrm{NH}_{4}-\mathrm{N}$ uptake (Tank et al. 2000; $\mathrm{g} \mathrm{m}^{-2} \mathrm{~d}^{-1}$ ) & \multicolumn{3}{|c|}{0.19} \\
\hline River area from WWTP to station $\left(\mathrm{m}^{2}\right)$ & \multirow{6}{*}{$\begin{array}{l}58456 \\
4.1 \\
1972-1995\end{array}$} & 12431 & 46092 \\
\hline Nitrified $\mathrm{NH}_{4}-\mathrm{N}\left(\mathrm{t} \mathrm{a}^{-1}\right)$ & & 0.9 & 3.2 \\
\hline Years of selected time series & & 1995-2011 & 1976-2011 \\
\hline Total uptake over time (t N) & & 107.0 & 111.9 \\
\hline Total $\mathrm{NO}_{3}-\mathrm{N}$ export over time $(\mathrm{t})$ & & 3697 & 2146 \\
\hline Total uptake according to export (\%) & & 2.9 & 5.2 \\
\hline
\end{tabular}

15 


\section{S2 Addition to results}
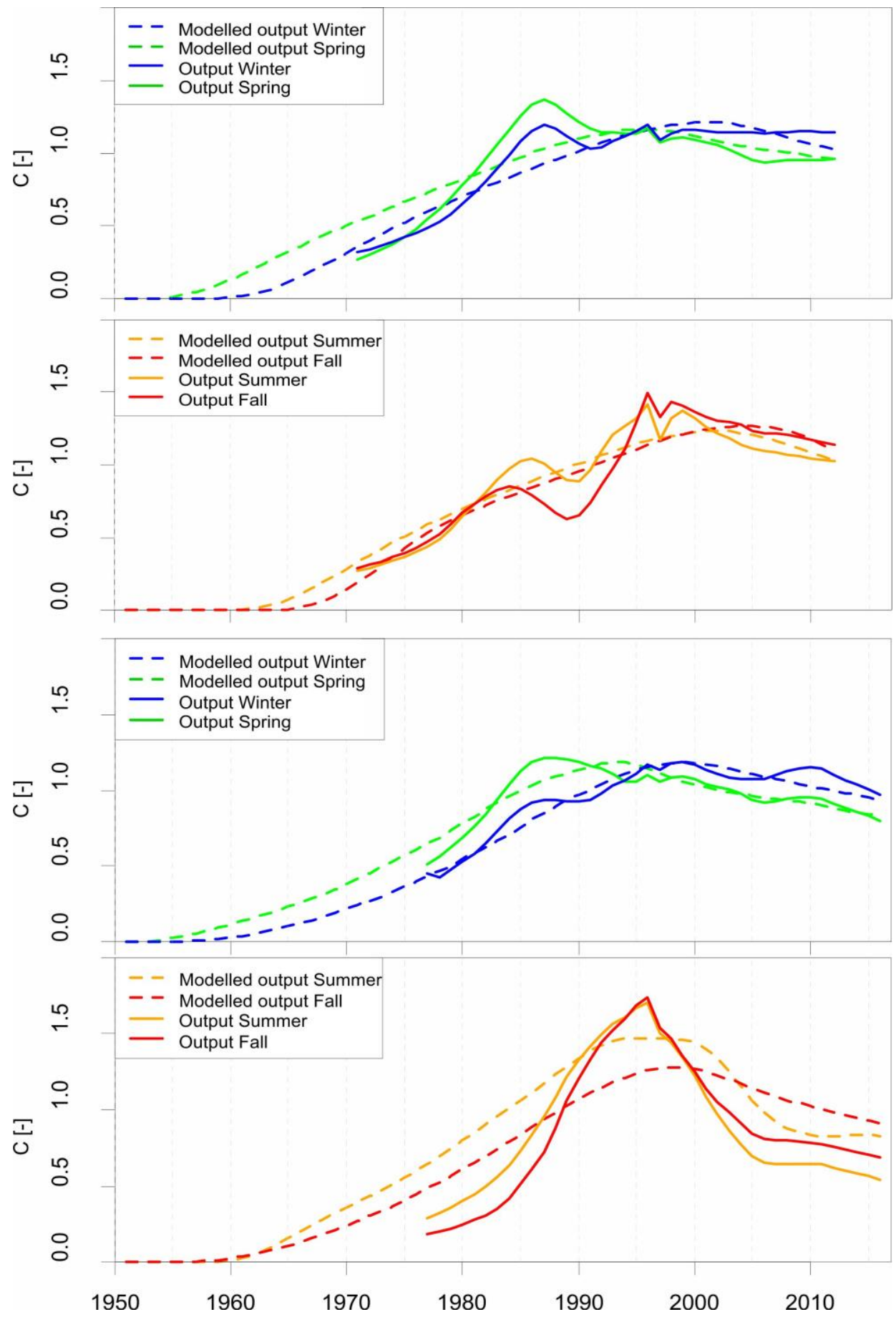

Figure S2.1: Modelled N-output concentrations derived from the $\mathrm{N}$-input convolved with the log-normal travel time distributions (dashed lines) and the scaled observed flow-normalized seasonal $\mathrm{NO}_{3}$-N concentrations (solid lines) over time. 


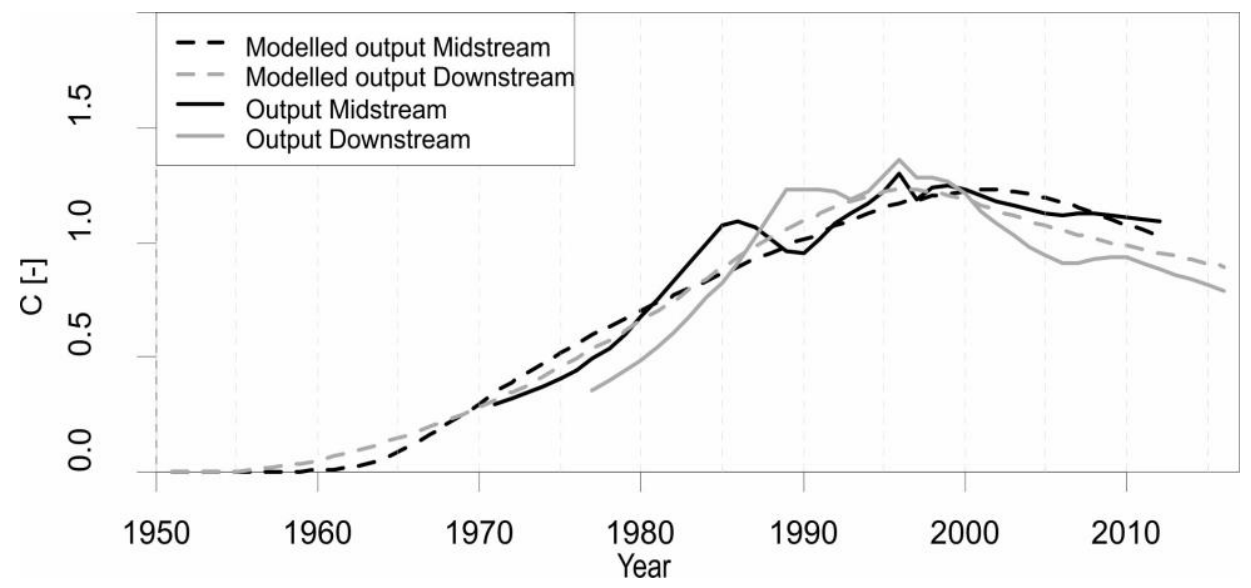

Figure S2.2: Modelled N-output concentrations derived from the N-input convolved with the log-normal travel time distributions (dashed lines) and the scaled observed flow-normalized annual $\mathrm{NO}_{3}-\mathrm{N}$ concentrations (solid lines) over time. 